\title{
Article
}

\section{The Design and Optimization of an Anti-Reflection Coating and an Intermediate Reflective Layer to Enhance Tandem Solar Cell Photons Capture}

\author{
Hassan Sayed ${ }^{1}$, Z. S. Matar ${ }^{2}$, M. Al-Dossari ${ }^{3}$, A. F. Amin ${ }^{4}$, N. S. Abd El-Gawaad ${ }^{5}$ and Arafa H. Aly ${ }^{1, *}$ \\ 1 TH-PPM Group, Physics Department, Faculty of Science, Beni-Suef University, Beni-Suef 62521, Egypt \\ 2 Department of Physics, Faculty of Applied Science, Umm Al-Qura University, Mecca 24382, Saudi Arabia \\ 3 Physics Department, King Khalid University, Dhahran Aljanoub, Abha 61421, Saudi Arabia \\ 4 Faculty of Technology and Education, Beni-Suef University, Beni Suef 62521, Egypt \\ 5 Faculty of Science, King Khalid University, Abha 61421, Saudi Arabia \\ * Correspondence: arafa.hussien@science.bsu.edu.eg or arafaaly@aucegypt.edu
}

check for

updates

Citation: Sayed, H.; Matar, Z.S.;

Al-Dossari, M.; Amin, A.F.;

El-Gawaad, N.S.A.; Aly, A.H. The Design and Optimization of an Anti-Reflection Coating and an Intermediate Reflective Layer to

Enhance Tandem Solar Cell Photons Capture. Crystals 2022, 12, 57.

https://doi.org/10.3390/ cryst12010057

Academic Editor: Bo Chen

Received: 8 November 2021

Accepted: 28 December 2021

Published: 31 December 2021

Publisher's Note: MDPI stays neutral with regard to jurisdictional claims in published maps and institutional affiliations.

Copyright: (c) 2021 by the authors Licensee MDPI, Basel, Switzerland. This article is an open access article distributed under the terms and conditions of the Creative Commons Attribution (CC BY) license (https:// creativecommons.org/licenses/by/ $4.0 /)$.

\begin{abstract}
We have theoretically demonstrated an efficient way to improve the optical properties of an anti-reflection coating (ARC) and an intermediate reflective layer (IRL) to enhance tandem solar cell efficiency by localizing the incident photons' energy on a suitable sub-cell. The optimum designed ARC from a one-dimensional ternary photonic crystal, consisting of a layer of silicon oxynitride $(\mathrm{SiON})$, was immersed between two layers of $\left(\mathrm{SiO}_{2}\right)$; thicknesses were chosen to be $98 \mathrm{~nm}, 48 \mathrm{~nm}$, and $8 \mathrm{~nm}$, respectively. The numerical results show the interesting transmission properties of the anti-reflection coating on the viable and near IR spectrum. The IRL was designed from one-dimensional binary photonic crystals and the constituent materials are $\mathrm{Bi}_{4} \mathrm{Ge}_{3} \mathrm{O}_{12}$ and $\mu \mathrm{c}-\mathrm{SiO}_{\mathrm{x}}: \mathrm{H}$ with refractive indexes was 2.05 , and 2.8 , respectively. The numbers of periods were set to 10. Thicknesses: $d_{1}=62 \mathrm{~nm}$ and $d_{2}=40 \mathrm{~nm}$ created a photonic bandgap (PBG) in the range of [420 nm: $540 \mathrm{~nm}$ ]. By increasing the second material thickness to $55 \mathrm{~nm}$, and $73 \mathrm{~nm}$, the PBG shifted to longer wavelengths: [520 nm: $630 \mathrm{~nm}$ ], and [620 nm: $730 \mathrm{~nm}$ ], respectively. Thus, by stacking the three remaining structures, the PBG widened and extended from $400 \mathrm{~nm}$ to $730 \mathrm{~nm}$. The current theoretical and simulation methods are based on the fundamentals of the transfer matrix method and finite difference time domain method.
\end{abstract}

Keywords: tandem solar cell; intermediate reflective layers; photonic crystals; anti-reflection

\section{Introduction}

Many experts from all around the world have recently focused their attention on the solar cell industry's low efficiency. The probability of absorption could offer the ability to understand the limitations of solar cell efficiency [1-4]. As a result, enhancing solar cell efficiency is highly dependent on identifying energy losses and being able to minimize them $[5,6]$. Thus, to compute the loss of energy, we divided incident electromagnetic waves (photons) energy into three parts, with respect to the energy gap of the active layer of the cell. Beginning with longer wavelengths (lower energy) for photons with energy lower than the energy gap $\left(E_{g}\right)$ of the cell, these photons were transmitted to the back contact of the cell without any generation. Then, for the incident photons with energy equal to $E_{g}$ of the absorber layer, electron-hole pairs were generated without any energy losses. Finally, for the third part of incident photons with energy greater than $E_{g}$ of the absorber, photons generated electron-hole pairs, and the excess energy was converted to lattice vibration (phonons), which is considered as power dissipation in the form of thermal energy. In particular, the electrons occupy the energy levels at the conduction band bottom, wherein, the holes are situated at the top of the valence band, respectively [7,8]. Therefore, the non-absorbed photons and thermal energy were the two major losses that affected 
negatively on the efficiency of the cell. Moreover, other parameters, such as incomplete absorption due to the finite thickness, the total reflection from the top surface, shading, the recombination, and the metal electrode coverage were present [9]. Therefore, there are several methods to eliminate the remaining shortcomings in conversion efficiency, such as inserting an anti-reflection coating (ARC) and designing a multi-energy gap cell (tandem cell), and back reflector [10-12].

A tandem solar cell is considered a multi-junction cell with different energy gaps, with a higher energy gap at the top and a lower energy gap at the bottom. They have recently attracted significant attention due to their high conversion power over a wide energy spectrum; however, owing to their high manufacturing costs, they are not widely used in the commercial market. On the other hand, the use of the two junctions of tandem solar cells is widespread due to their high efficiency concerning cost. In this case, an intermediate reflective layer (IRL) is inserted between the high energy gap (top cell) and the lower energy gap (bottom cell) [13,14], acting as a filter between the two subcells. However, it must justify the following conditions: high reflectance in the spectrum region of low absorption of the top cell, strong conductivity to avoid ohmic losses, and high transmission in the spectral region of insignificant absorption of the bottom cell. Thus, IRL is also responsible for photon management, which results from the delivery of photons to different layers based on their quantum energy. In other words, the IRL localizes the photon in the suitable cell. In addition, the total reflection from the top surface causes limited efficiency, as the reflectance of the silicon solar cell reaches $37 \%$ from the total incident electromagnetic waves due to the high dielectric contrast between the air and silicon $[7,15]$. Therefore, to overcome this defect, we inserted a planner ARC on the surface of the cell to reduce the incident power dissipation due to reflection.

Hence, we aimed to limit the power dissipations in the tandem solar cell using artificial materials called photonic crystals [16-21] or photonic bandgap materials. Photonic crystals (PCs) are periodic and artificial structures with periodic modulates (dielectric constants) and are employed in different applications due to their unique properties [22-25]. PCs have received great attention in recent years due to their unique properties such as the presence of the so-called photonic bandgap (PBG). Therefore, due to their low cost and wide range of applications, PCs may play a key role in improving tandem solar cell efficiency, particularly in one-dimensional photonic crystals (1DPCs).

Antireflective coatings and surface texturization have traditionally been used to improve bulk silicon solar cells [26-29]. Several PCs have been created to reduce silicon surface reflectance for solar cell applications [30]. In the literature survey, the typical reflection of the standard bulk silicon solar cell is $16 \%$; these measurements were made on a conventional silicon solar cell that had been texturized with inverted pyramids, using a chemical technique at the National Renewable Energy Center (CENER) without any antireflection coating [31]. Moreover, by adding an ARC for solar cells, we observed the reflectance of a bulk silicon solar cell, texturized with inverted pyramids by a common industrial technique. The designed one-dimensional PCs with three different types: rectangular, triangular, and circular shapes were studied in [32]. As a result, a remarkable enhancement in reducing cell reflectance was achieved as the following: The best structure was discovered to be a triangular PC with pitch and height dimensions of $460 \mathrm{~nm}$ and $323 \mathrm{~nm}$, respectively. Thus, the average reflectance of a Si solar cell with ARC, in the form of a triangular PC, in the range of wavelength from $400 \mathrm{~nm}$ to $1100 \mathrm{~nm}$, is reduced from 35.88 percent to 10.6 percent. Moreover, the best rectangular and circular ARC from 1DPCs reduces the reflectance to 15.9 and 17.13 percent, respectively. The power dissipation by reflection remains the best method and the structures of triangular, rectangular, and circular ARC are costly in manufacturing. Furthermore, alternative morphologies, such as the 3D bionic Si photocathode with $\mathrm{TiO}_{2} / \mathrm{MoS}_{2}$, reduce the electrode's reflectivity to $3 \%$ and considerably boost its light adsorption capacity [33-35]. Additionally, employing self-assembled polymer sphere monolayers as etching masks creates antireflective $\mathrm{Si}$ nanopillar arrays. The reflectivity of the Si wafer was lowered by using Si nanopillar arrays 
with antireflective behaviour, generated by combining self-assembled polymer spheres into two-dimensional (2D) arrays and reactive-ion etching (RIE) from above 32 percent to below 8 percent [36-38]. Several approaches based on self-assembly masks, such as anodic porous aluminium [39], spin-coated spheres [40,41], and evaporated Ag islands [42], were used to construct these last structures. As a result of the high expense of practical procedures, we aimed to develop a basic structure with a low cost-effective and a high transmission planner surface.

The motivation of this paper is to use 1D-PCs for designing each ARC and IRL with low cost and high efficiency to enhance the optical properties of the tandem solar cell. Firstly, ARC was characterized by high transmission to reduce the reflectance of the cell. Then, the IRL assisted to localize the photon energy in the suitable cell. Finally, in combination between ARC and IRL with PCs, we observed an enhancement in the conversion efficiency of the considered tandem solar cell. The numerical and the simulation results were investigated based on the fundamentals of the finite difference time domain method (FDTD) and transfer matrix method (TMM).

\section{Modeling}

In this part, our modeling and simulation procedure is displayed in two parts. Firstly, we designed one-dimensional ternary PCs with high transmission properties to act as an anti-reflection coating. Then, in the second part, we designed the IRL from one-dimensional binary PCs. Wherein, the mean propose of the IRL is the localization of the incident photons through the suitable sub-cell by controlling the range of the PBG. For the theoretical studies, we used the fundamentals of TMM $[43,44]$ as the analytical method, and we use the FDTD $[45,46]$ in the same lumerical software as the simulation method.

\subsection{Anti Reflection Coating (ARC)}

Owing to the high dielectric contrast between the air and amorphous silicon, a large portion of the incident electromagnetic waves is reflected from the top surface of the cell. Therefore, the presence of a planar ARC on the top of the cell could reduce the dielectric contrast between the air and the first layer of the cell $[47,48]$. Thus, we can minimize the reflection of the incident light on the surface of the cell. The optical thickness of the simple solar cell, which consists of an optically homogeneous slab, is given by Equation (1) [7]:

$$
d_{o p t}=n d \cos ^{-1} \theta_{2}
$$

where, $n$ is the refractive index of the cell, $d$ is the thickness of the cell and $\theta_{2}$ is the angle of refraction inside the cell.

Here, we designed a planar ARC from 1D ternary PCs (i.e., three materials with different indices of refraction and thicknesses stacked together). Our structure consisted of a layer of aluminium-doped with zinc oxide $(\mathrm{Al}$ : $\mathrm{ZnO})$ with refractive index $(\mathrm{n})=2$ [49] arranged between two layers of silicon dioxide $\left(\mathrm{SiO}_{2}\right)$ with refractive index $(\mathrm{n})=1.45$ [49], as shown in Figure 1. Here, the thickness of the $\mathrm{Al}$ : $\mathrm{ZnO}$ layer was set to $48 \mathrm{~nm}$, wherein the thicknesses of the two $\mathrm{SiO}_{2}$ layers were chosen to be $98 \mathrm{~nm}$ and $8 \mathrm{~nm}$. The simulation procedure for this considered structure is essentially based on the finite difference time domain (FDTD) method that was prepared using Lumerical software [50]. 


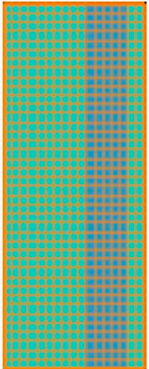

(a)

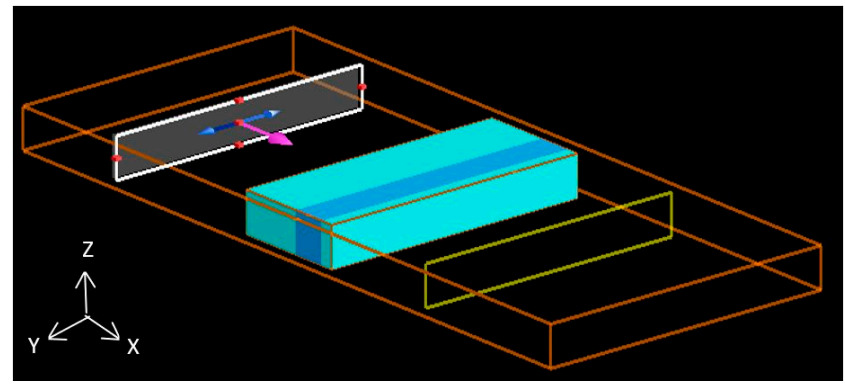

(b)

Figure 1. (a) Schematic structure of ARC with the meshing of XY plane. (b)The full structure of simulation procedure at three dimensions by FDTD, which consist of plane wave source (white color), the designed structure (sky and blue color), the monitor (yellow color), and FDTD domain (orange color).

\subsection{Intermediate Reflective Layer (IRL)}

The intermediate reflective layer was inserted between the hydrogenated amorphous silicon (top cell) with a higher energy gap $\left(E_{g} \approx 1.7 \mathrm{eV}\right)$ and the microcrystalline silicon (bottom cell) with a lower energy gap $\left(E_{g} \approx 1.1 \mathrm{eV}\right)$, as we have shown in Figure 2. The role of the IRL was to reflect the non-absorbed photon with the shorter wavelength to the top cell and transmit the longer wavelength to the bottom cell. IRL thereby acts as a back reflector for the top cell and as a window for the bottom cell. Thus, the IRL is designed from a one-dimensional binary photonic crystal (i.e., two material layers constituting a period of lattice) [51,52] that is repeated for $\mathrm{N}$ periods. Here, the IRL structure is designed from $\mathrm{Bi}_{4} \mathrm{Ge}_{3} \mathrm{O}_{12}$ of refractive indices 2.05 [52] and $\mu \mathrm{c}-\mathrm{SiO}_{\mathrm{x}}$ : $\mathrm{H}$ of refractive indices 2.8 [53].

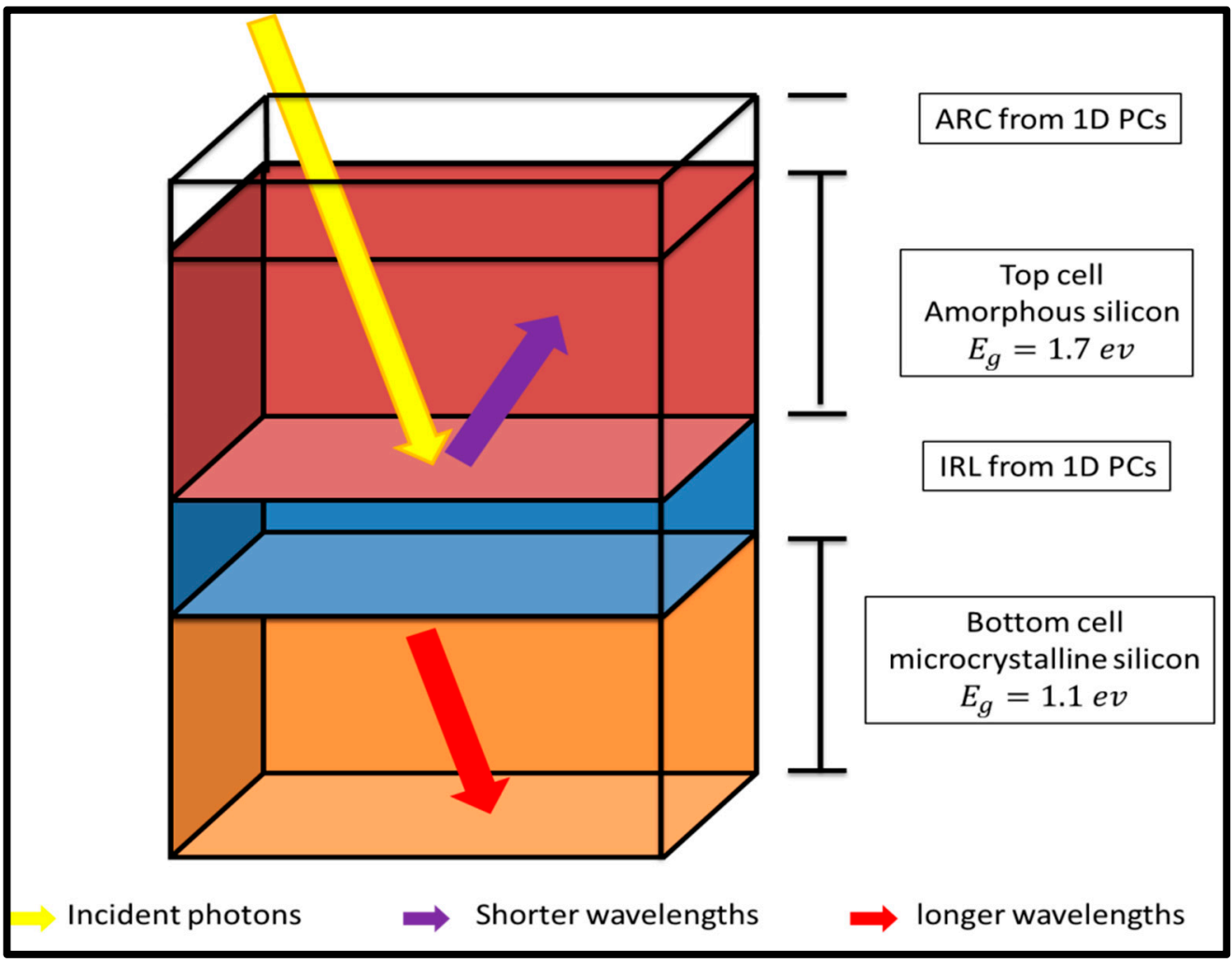

Figure 2. Schematic structure of tandem solar cell with anti-reflection coating and the intermediate reflective layer. 


\section{Result and Discussion}

Here, the results and discussions are displayed through two parts, firstly, we present the numerical and the simulation results of the considered structures of ARC. Then, in the second part, we optimize the considered structure of IRL by using the two different methods (FDTD and TMM). The IRL is also chosen to be highly reflected for shorter wavelengths photons [300-730 nm], and highly transmitted for longer wavelengths photons [730-1100 nm].

\section{1. $A R C$}

We investigated the transmission characteristics of the ARC, designed from a single period of 1D ternary PCs, as we discussed previously in Section 2.1. Here, the thickness of the aluminum doped with zinc oxide $(\mathrm{Al}: \mathrm{ZnO})$ layer was set to be $48 \mathrm{~nm}$, wherein the thicknesses of the two-silicon dioxide $\mathrm{SiO}_{2}$ layers were chosen to be $98 \mathrm{~nm}$ and $8 \mathrm{~nm}$, respectively. Figure 3 shows the transmission characteristics of our design. The figure shows that the values of transmission are almost greater than $80 \%$ through the overall wavelengths of the incident electromagnetic radiations. For further enhancement within the transmission values, we replaced the ( $\mathrm{Al}: \mathrm{ZnO})$ of refractive index $=2$ [53] with silicon oxynitride $(\mathrm{SiON})$ of refractive index $=1.59$, the extinction coefficient $\mathrm{k}$ is zero [54], the thickness was set to be $48 \mathrm{~nm}$. Wherein, SiON was used for light tapping in solar cell application due to its high transmittance. For the light trapping efficiency (LTE) and light transmission of solar cells, a simple and cost-effective was proposed in this work. For the survey about $\mathrm{SiON}$, the prepared thick film of $\mathrm{SiON}$ was characterized by a good transmittance of approximately $95 \%$ in the visible-light spectrum [55]. Additionally, the silicon nitride $(\mathrm{SiN})$ light transmittance curve is approximately close to $\mathrm{SiON}$ and good in the solar cell light absorption range, making it suitable for application in solar cell antireflection coatings with $\mathrm{SiON}$ and high transmission with respect to $\mathrm{SiN}$ in the visible spectrum [56]. However, these single layers have good transmittance in visible light only and for our tandem solar cell structure, ARC is necessary for high transmittance in the visible and near IR spectrum (from $300 \mathrm{~nm}$ to $1100 \mathrm{~nm}$ ). Therefore, a different multilayer structure was used to enhance the light trapping of the solar cell as the combination of $\mathrm{SiON}$ with $\mathrm{SiN}$ to form a multilayer anti-reflection coating on the front side of selective emitter solar cells [57]. Moreover, we used the combination from $\mathrm{SiO}_{2}$ and $\mathrm{SiON}$ to obtain high transmission in the required range of wavelengths [58-61]. We observed that the transmission values increased to reach the unity in the visible spectrum which exceeded the designed ARC in the form of a triangular PC with transmittance equal 89.4 percent [32]. Therefore, we were able to overcome a large portion of energy losses by reflection by using a planner ARC of low refractive index materials of $\mathrm{SiO}_{2}$ and $\mathrm{SiON}$ at a wide range of the solar spectrum (from $400 \mathrm{~nm}$ to $1100 \mathrm{~nm}$ ) which is suitable for a two-junction tandem solar cell.

Then, we studied the effect of inserting the optimized ARC structure on the top surface of the hydrogenated amorphous silicon (a-Si: $\mathrm{H}$ ) top cell, focusing on the interface between the dielectric ARC and the semiconductor material, owing to the dielectric contrast for the two materials [62,63]. Thus, we studied the effect of the third layer of ARC thickness on the transmission spectrum, as shown in Figure 4. The appearance of a transmission peak through the visible region is shown in Figure 4; this peak shifts towards the longer wavelengths with the increment of the third layer of the $\mathrm{ARC}\left(\mathrm{SiO}_{2}\right.$ layer). These longer wavelengths have a small amount of energy and little intensity in the solar spectrum (AM1.5). Thus, the amount of incident energy that reached the active area of the cell was decreased by increasing the thickness of the third layer of ARC. Accordingly, we fixed the thickness of the third layer at $8 \mathrm{~nm}$ to increase the transmission, and to reduce overall the reflection from the surface of the structure, especially in the visible spectrum $[64,65]$. Finally, we added Table 1 to compare our present work and the previous works in the literature survey to show the motivation and novelty of our work. 


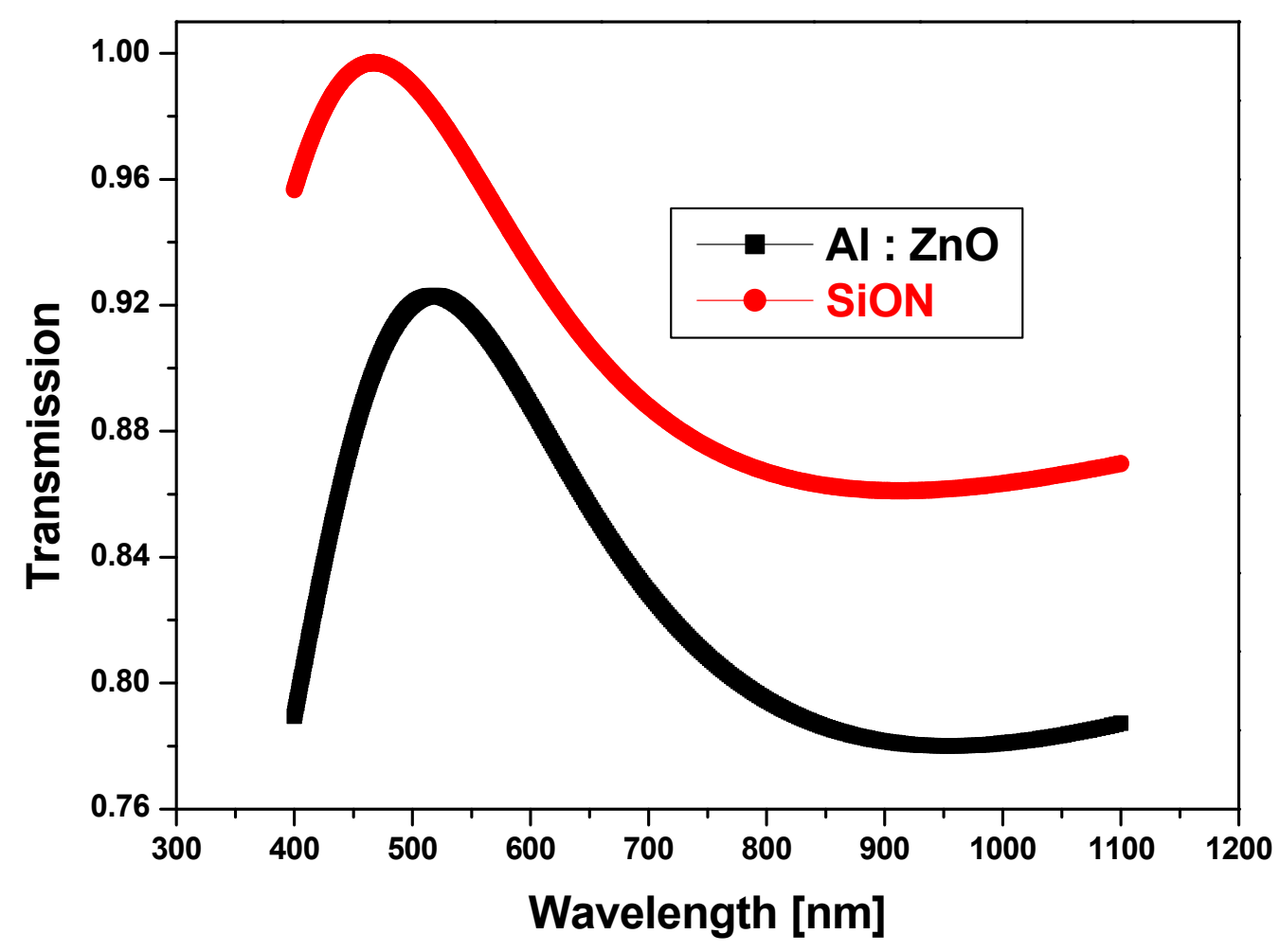

Figure 3. Transmission spectrum of 1D ternary PCs for one period with different embedded materials.

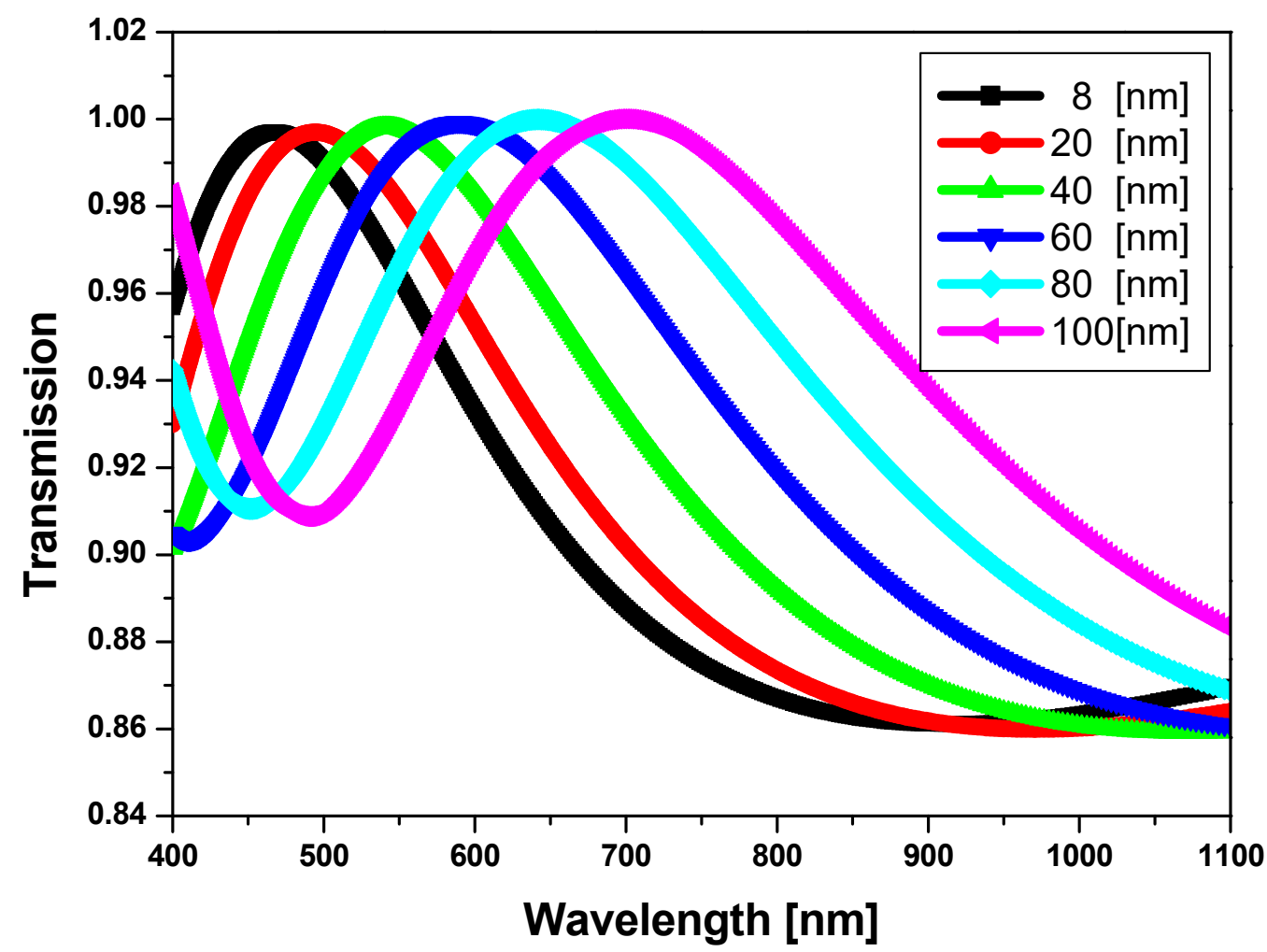

Figure 4. Transmission behavior of the structure with different thicknesses of the third layer of dielectric ARC and thicknesses of $98 \mathrm{~nm}, 45 \mathrm{~nm}$ for the first and second layer, respectively. 
Table 1. The average reflection of antireflection coating designs for the remarkable results found in the literature in comparison with our work.

\begin{tabular}{|c|c|c|c|}
\hline $\begin{array}{c}\text { Anti-Reflection Coating } \\
\text { Design }\end{array}$ & $\begin{array}{l}\text { Average Reflectance }(\%) \\
\quad[400-1000 \mathrm{~nm}]\end{array}$ & $\begin{array}{l}\text { Average Reflectance (\%) } \\
\text { [500-700 nm] }\end{array}$ & Reference \\
\hline Polished silicon & 33.4 & 35.88 & {$[7,8]$} \\
\hline Standard Silicon solar cell & 16.75 & 16.23 & [31] \\
\hline Rectangular PC profile & 15.04 & 15.9 & [32] \\
\hline Triangular PC profile & 10.68 & 10.6 & {$[32,66]$} \\
\hline Circular PC profile & 16.99 & 17.13 & [32] \\
\hline $1 \mathrm{D}$ rectangular PC & $23.25 / 15.26$ & $26 / 14.08$ & [66] \\
\hline $1 \mathrm{D}$ triangular $\mathrm{PC}$ & $6.93 / 19.95$ & $7.01 / 16.62$ & [67] \\
\hline 1D planner PCs & 8 & 6 & Our work \\
\hline
\end{tabular}

\subsection{IRL}

Here, we present the numerical results of the IRL designed from one-dimensional binary PCs. We used two different dielectric materials $\left(\mathrm{Bi}_{4} \mathrm{Ge}_{3} \mathrm{O}_{12}\right.$ and $\mu \mathrm{c}-\mathrm{SiO}_{\mathrm{x}}$ : $\left.\mathrm{H}\right)$ that were repeated for $\mathrm{N}$ periods to design the IRL. The $\mathrm{Bi}_{4} \mathrm{Ge}_{3} \mathrm{O}_{12}$ layer is characterized by a refractive index of 2.05 and thickness $d_{1}=62 \mathrm{~nm}$. Wherein, the $\mu c-\mathrm{SiO}_{\mathrm{x}}: \mathrm{H}$ layer is specified with a refractive index of 2.8 and thickness $d_{2}=55 \mathrm{~nm}$. Firstly, we investigated the effect of the number of periods on the transmission properties of the considered IRL, as shown in Figure 5. The figure shows the appearance of the PBG within the visible region for $\mathrm{N}=5$ and 7; the transmission values within the PBG are greater than 0.1. In addition, the transmission values within the PBG are almost zero when the number of periods is set to 10 . Thus, we set $\mathrm{N}=10$ periods as the optimum condition in our application as well as due to the unique properties, principal of photonic crystals. In Figure 5, the resonance peaks are generated due to the interferences of the reflected photons in each interface, thus, for $n$ periods equal to 5 , the number of interfaces is small which affected the PBG and the symmetry of the resonance peaks. Additionally, the increasing number of periods caused an increase in the number of interfaces to enhance the PBG and increase the symmetry of the resonance peaks, as we have shown. Moreover, increasing, the number of periods above 10 is expected to increase the symmetry of the resonance peaks. For more control of the properties of the PBG, we studied the effect of the thickness of the second layer on the position and width of the PBG. We observed that the PBG shifted to a longer wavelength, as shown in Figure 6a,b. This explains why PBG depends on several parameters such as the refractive index mismatch between the two layers and the thickness of each layer. Additionally, we confirmed these results by two different methods: TMM in Figure 6b and simulated procedure by FDTD in Figure 6a. These results explain how we can control and localize the electromagnetic waves by PBG and confirm the results by two methods: TMM and FDTD, which completely matched. For more details, we calculated the PBG by dispersion relation for the same structure, as shown in Figure $6 c$, which completely matched with the PBG range of the transmission spectrum, as shown in Figure 6a,b.

Finally, for a more convenient IRL suitable for the tandem solar cell, we obtained a new design of the IRL that almost covers the visible region. The new IRL is composed of three identical structures of the previous IRL but with different thicknesses of the second material, as shown in Figure 7a. The PBG extend over a wide range from $420 \mathrm{~nm}$ to $730 \mathrm{~nm}$, as shown in Figure $7 \mathrm{~b}$ with TMM and also in Figure 7c, which was calculated with the FDTD method. Thus, the two methods approve the results, due to the matching spectrum in the range of PBG, as shown. Moreover, the transmission values exceed 0.4 in the range from $730 \mathrm{~nm}$ to $1100 \mathrm{~nm}$. In addition, the two methods slightly differ only on the resonance peaks due to the boundary conditions of each method. The reason for the choice of these wavelength regions depends on the energy gap for each cell. The top cell is characterized 
by an energy gap equivalent to $1.7 \mathrm{eV}$. Therefore, it will absorb approximately all incident photons that possess energy higher than $1.7 \mathrm{eV}$, which corresponds to the wavelengths smaller than $730 \mathrm{~nm}$. For these reasons, we chose the PBG in this range with a reflection reaching approximately $100 \%$ to act as an aback reflector to the top cell. Moreover, for the wavelength region from $730 \mathrm{~nm}$ to $1100 \mathrm{~nm}$, our structure acts as a window or ARC for the bottom cell because of the high values of the transmission. Finally, our results verify the optimum condition for ARC and IRL for an efficient tandem solar cell. In other words, the combination between IRL and ARC in the tandem solar cell could overcome a large portion of power dissipation and enhance its optical efficiency.

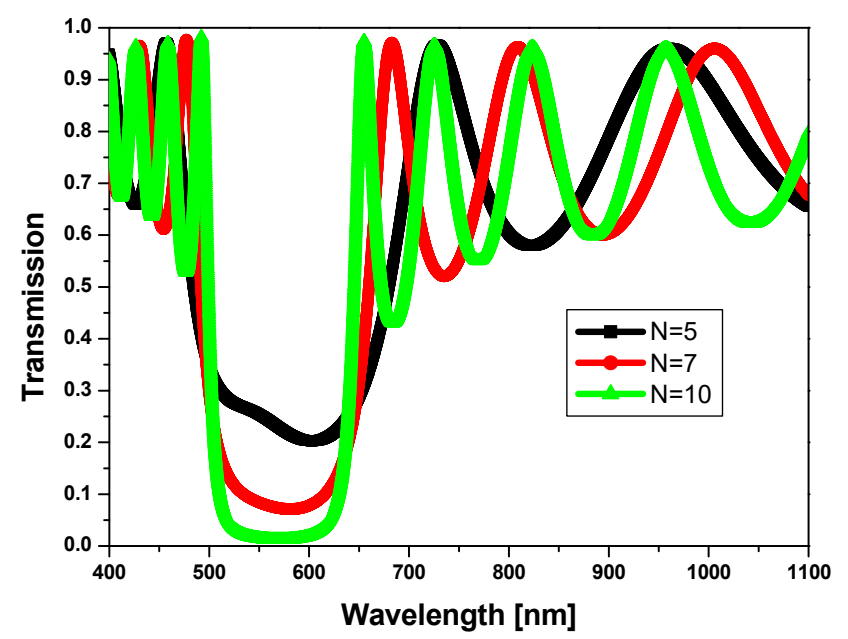

Figure 5. The transmission spectrum of $1 \mathrm{D}$ binary photonic crystals of $\mathrm{Bi}_{4} \mathrm{Ge}_{3} \mathrm{O}_{12}$ with thickness $d_{1}=62 \mathrm{~nm}$ and $\mu \mathrm{c}-\mathrm{SiO}_{\mathrm{x}}: \mathrm{H}$ with thickness $d_{2}=55 \mathrm{~nm}$, with a different number of the period as shown.

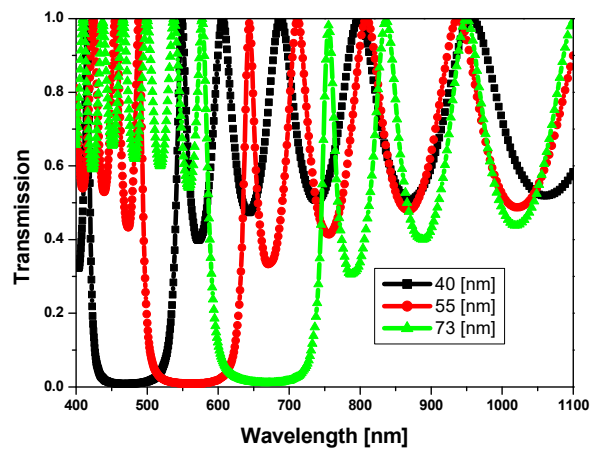

(a)

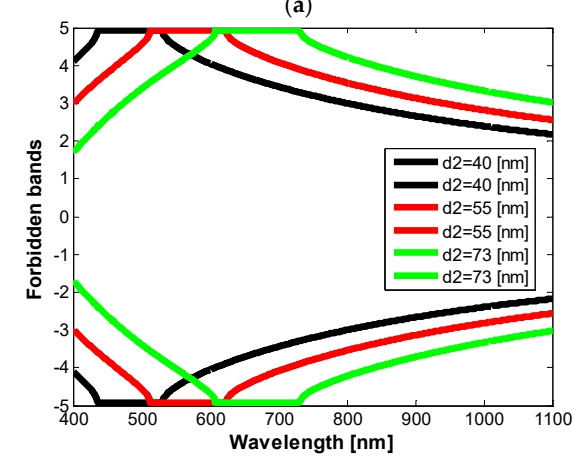

(c)

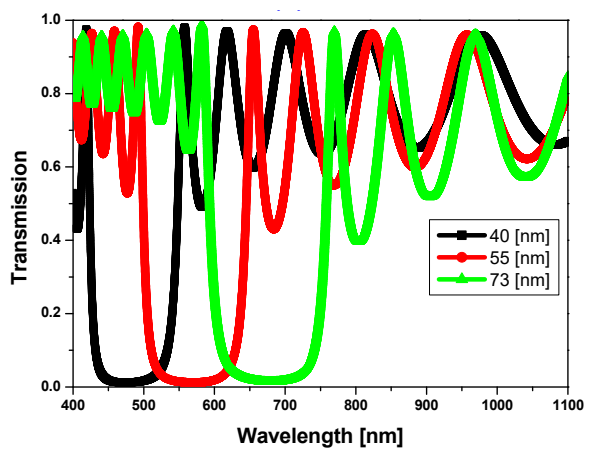

(b)

Figure 6. $1 \mathrm{D}$ binary photonic crystals of $\mathrm{Bi}_{4} \mathrm{Ge}_{3} \mathrm{O}_{12}$ with thickness $62 \mathrm{~nm}$ and $\mu \mathrm{c}-\mathrm{SiO}_{\mathrm{x}}$ : $\mathrm{H}$ with different thicknesses for ten periods as shown (a) by FDTD, (b) by TMM, (c) dispersion relation of the same structure by TMM. 


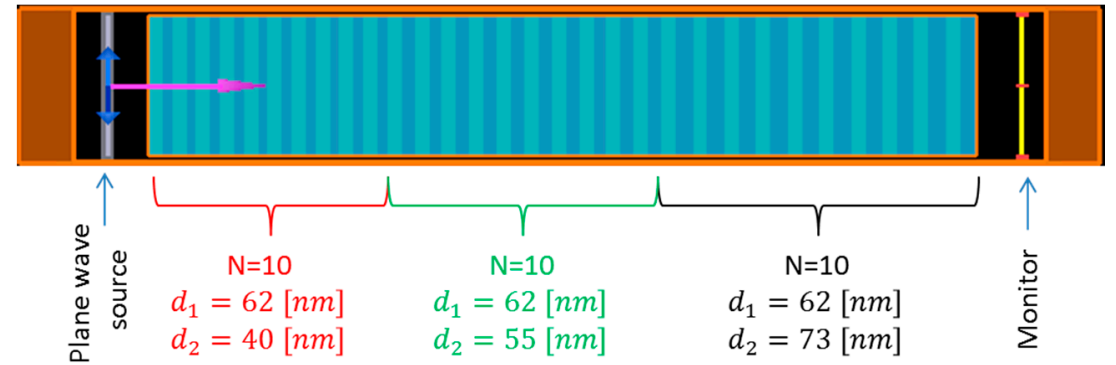

(a)
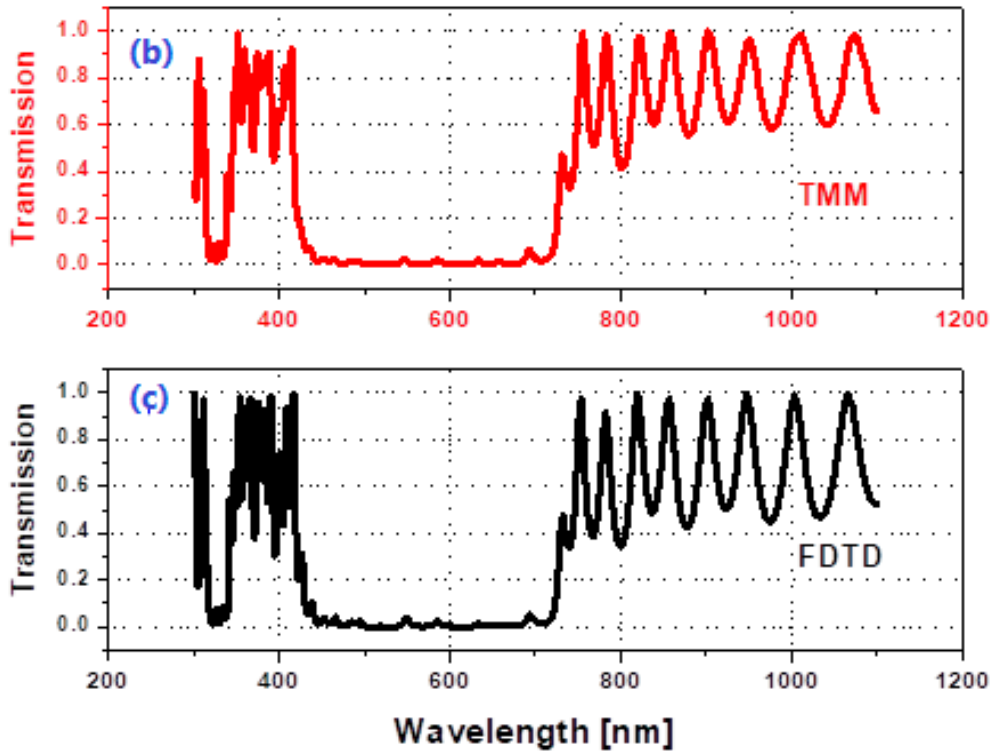

Figure 7. $1 \mathrm{D}$ binary photonic crystals of $\mathrm{Bi}_{4} \mathrm{Ge}_{3} \mathrm{O}_{12}$ with thickness $62 \mathrm{~nm}$ and $\mu \mathrm{c}-\mathrm{SiO}_{\mathrm{x}}=\mathrm{H}$ with $40 \mathrm{~nm}$, $55 \mathrm{~nm}$, and $73 \mathrm{~nm}$; (a) Schematic structure of considered the structure, (b) Transmission behavior for the structure by MATLAB based on TMM, and (c) Transmission behavior for the structure by lumerical based on FDTD.

\section{Conclusions}

In this paper, we designed a significant structure for each ARC and IRL by using the fundamental properties of one-dimensional photonic crystals to reduce a massive portion of power dissipation within the tandem solar cell. Here, the considered structure of ARC and IRL shows its ability to control the transmission characteristics of the incident electromagnetic radiation through the cell. Firstly, the designed ARC consists of a layer of silicon oxynitride $(\mathrm{SiON})$ of refractive index $=1.59$, with a thickness equal to $48 \mathrm{~nm}$, embedded between two layers of silicon dioxide $\mathrm{SiO}_{2}$ with thicknesses chosen to be $98 \mathrm{~nm}$, and $8 \mathrm{~nm}$, respectively. We observed that the transmission values reached the unity in the visible spectrum, exceeding the designed ARC in the form of a triangular PC with transmittance equal 89.4 percent. Then, we designed an IRL from 1D binary photonic crystals of $\mathrm{Bi}_{4} \mathrm{Ge}_{3} \mathrm{O}_{12}$ with thickness of $62 \mathrm{~nm}$ and $\mu \mathrm{c}-\mathrm{SiO}_{\mathrm{x}}$ : $\mathrm{H}$ with $40 \mathrm{~nm}, 55 \mathrm{~nm}$, and $73 \mathrm{~nm}$ for the first 10 periods, the second 10 periods and the third 10 periods, respectively. The considered structure of photonic crystals yielded PBG in the range of wavelengths from $400 \mathrm{~nm}$ to $730 \mathrm{~nm}$ and PBG acted as a back reflector to the top cell of amorphous silicon with an energy gap equal to $1.7 \mathrm{eV}$. Additionally, the designed IRL has high transmission properties in the range of wavelengths from $730 \mathrm{~nm}$ to $1100 \mathrm{~nm}$, which act as a window for the bottom cell of microcrystalline silicon, with an energy gap equal to $1.1 \mathrm{eV}$. The theoretical and simulation procedure is based on each TMM and FDTD method. Therefore, the combination between IRL and ARC in the tandem solar cell can optically improve solar cell efficiency. 


\begin{abstract}
Author Contributions: Conceptualization, H.S. and A.H.A.; methodology, H.S.; software, H.S.; validation, A.H.A., Z.S.M. and M.A.-D.; formal analysis, A.F.A.; investigation, A.H.A.; resources, Z.S.M. and N.S.A.E.-G.; data curation, N.S.A.E.-G., A.F.A. and M.A.-D.; writing-original draft preparation, H.S.; writing-review and editing, A.H.A. and M.A.-D.; visualization, A.F.A.; supervision, A.H.A.; project administration, H.S.; funding acquisition, Z.S.M., M.A.-D. and N.S.A.E.-G. All authors have read and agreed to the published version of the manuscript.
\end{abstract}

Funding: This research funded by STDF, Egypt. This paper is based upon work supported by Science, Technology \& Innova-tion Funding Authority (STDF) under grant Post Graduate Support Grant (PGSG) under with grant number 44871.

Data Availability Statement: Not applicable.

Conflicts of Interest: The authors declare that there are no conflict of interest.

\title{
References
}

1. Sai, H.; Matsui, T.; Saito, K.; Kondo, M.; Yoshida, I. Photocurrent enhancement in thin film silicon solar cells by combination of anti-reflective sub-wavelength structures and light-trapping textures. Prog. Photovolt. 2015, 23, 1572-1580. [CrossRef]

2. Guo, K.W. Green nanotechnology of trends in future energy: A review. Int. J. Energy Res. 2012, 36, 1-17. [CrossRef]

3. Herzinger, C.; Johs, B.; McGahan, W.; Woollam, J.; Paulson, W. Ellipsometric determination of optical constants for silicon and thermally grown silicon dioxide via a multi-sample, multi-wavelength, multi-angle investigation. J. Appl. Phys. 1998, 83, 3323-3336. [CrossRef]

4. Kuang, P.; Eyderman, S.; Hsieh, M.L.; Post, A.; John, S.; Lin, S.Y. Achieving an accurate surface profile of a photonic crystal for near-unity solar absorption in a super thin film architecture. Acs Nano 2016, 10, 6116-6124. [CrossRef]

5. Lin, Y.Y.; Xu, Z.; Yu, D.L.; Lu, L.F.; Yin, M.; Tavakoli, M.M.; Chen, X.Y.; Hao, Y.Y.; Fan, Z.Y.; Cui, Y.X.; et al. Dual-layer nanostructured flexible thin-film amorphous silicon solar cells with enhanced light harvesting and photoelectric conversion efficiency. ACS Appl. Mater. Interfaces 2016, 8, 10929-10936. [CrossRef] [PubMed]

6. Kuang, P.; Deinega, A.; Hsieh, M.-L.; John, S.; Lin, S.-Y. Light trapping and near-unity solar absorption in a three-dimensional photonic-crystal. Opt. Lett. 2013, 38, 4200. [CrossRef]

7. Aly, A.H.; Sayed, H. Computer simulation and modeling of solar energy based on photonic band gap materials. Opt. Appl. (OA) 2018, 48, 117-126.

8. Sprafke, A.N.; Wehrspohn, R.B. Light Trapping Concepts for Photon Management in Solar Cells. Green 2012, 2, 177-187. [CrossRef]

9. Green, M. Third Generation Photovoltaics Advanced Solar Energy Conversion; Springer: Berlin/Heidelberg, Germany, 2003.

10. Li, T. Enhancement of light absorption in thin film silicon solar cells with light traping. Chin. J. Lumin. 2016, 37, 816-822.

11. Rand, B.; Peumans, P.; Forrest, S.R. Long-range absorption enhancement in organic tandem thin-film solar cells containing silver nanoclusters. J. Appl. Phys. 2012, 96, 7519. [CrossRef]

12. Brendel, R.; Hirsch, M.; Plieninger, R.; Werner, J. Quantum efficiency analysis of thin-layer silicon solar cells with back surface fields and optical confinement. IEEE Trans. Electron Devices 1996, 43, 1104-1113. [CrossRef]

13. Wehrspohn, R.B.; Upping, J.; Beckers, T.; Carius, R. 3D Photonic Crystals for Photon Management in Solar Cells; SPIE: Bellingham, WA, USA, 2011.

14. Yamamoto, K.; Yoshimi, M.; Tawada, Y.; Fukuda, S.; Sawada, T.; Meguro, T.; Takata, H.; Suezaki, T.; Koi, Y.; Hayashi, K.; et al. Large area thin film Si module. Sol. Energy Mater. Solar Cells 2002, 74, 449-455. [CrossRef]

15. Narasimhan, V.K.; Cui, Y. Nanostructures for photon management in solar cells. Nanophotonics 2013, 2, 87-210. [CrossRef]

16. Aly, A.H.; Sayed, H. Enhancement of the solar cell based on nanophotonic crystals. J. Nanophotonics 2017, 11, 046020. [CrossRef]

17. Aly, A.H.; Sayed, H. Photonic band gap materials and monolayer Solar cell. Surf. Rev. Lett. 2018, 25, 1850103. [CrossRef]

18. Foster, S.; John, S. Light-trapping design for thin-film silicon-perovskite tandem solar cells. J. Appl. Phys. 2016, 120, 103103. [CrossRef]

19. Yablonovitch, E. Inhibited Spontaneous Emission in Solid-State Physics and Electronics. Phys. Rev. Lett. 1987, 58, 2059-2062. [CrossRef]

20. Chutinan, A.; Kherani, N.P.; Zukotynski, S. High-efficiency photonic crystal solar cell architecture. Opt. Express 2009, 17, 8871-8878. [CrossRef] [PubMed]

21. Liu, W.; Ma, H.; Walsh, A. Advance in photonic crystal solar cells. Renew. Sustain. Energy Rev. 2019, 116, 109436. [CrossRef]

22. Aly, A.H.; Hsu, H.T.; Yang, T.J.; Wu, C.J.; Hwangbo, C.K. Extraordinary optical properties of a superconducting periodic multilayer near zero permittivity operation range. J. Appl. Phys. 2009, 105, 083917-6. [CrossRef]

23. Aly, A.H.; Elsayed, H.A.; Hamdy, H.S. The optical transmission characteristics in metallic photonic crystals. Mater. Chem. Phys. 2010, 124, 856-860. [CrossRef]

24. Trabelsi, Y.; Belhadj, W.; Ali, B.; Aly, A.H. Theoretical Study of Tunable Optical Resonators in Periodic and Quasiperiodic One-Dimensional Photonic Structures Incorporating a Nematic Liquid Crystal. Photonics 2021, 8, 150. [CrossRef]

25. A Ameen, A.; A Elsayed, H.; Alamri, S.; Matar, Z.; Al-Dossari, M.; Aly, A.H. Towards Promising Platform by Using Annular Photonic Crystals to Simulate and Design Useful Mask. Photonics 2021, 8, 349. [CrossRef] 
26. Green, M.A. Silicon solar cells: Evolution, high-efficiency design and efficiency enhancements. Semicond. Sci. Technol. 1993, 8, 1-12. [CrossRef]

27. Chattopadhyay, S.; Huang, Y.; Jen, Y.; Ganguly, A.; Chen, K.-H.; Chen, L. Anti-reflecting and photonic nanostructures. Mater. Sci. Eng. R: Rep. 2010, 69, 1-35. [CrossRef]

28. Rajteri, M.; Rastello, M.; Monticone, E. Antireflection coatings for superconducting photodetectors. Nucl. Instruments Methods Phys. Res. Sect. A: Accel. Spectrometers, Detect. Assoc. Equip. 2000, 444, 461-464. [CrossRef]

29. Zhao, J.; Green, M. Optimized antireflection coatings for high-efficiency silicon solar cells. IEEE Trans. Electron Devices 1991, 38, 1925-1934. [CrossRef]

30. Anderson, M.J.; Whitcomb, P.J. Design of Experiments. In Encyclopedia of Chemical Technology; Kirk, R.E., Othmer, D.F., Eds.; John Wiley \& Sons, Inc.: Hoboken, NJ, USA, 2000.

31. Yang, L.; Liu, Y.; Wang, Y.; Chen, W.; Chen, Q.; Wu, J.; Kuznetsov, A.; Du, X. 18.87\%-efficient inverted pyramid structured silicon solar cell by one-step Cu-assisted texturization technique. Sol. Energy Mater. Sol. Cells 2017, 166, 121-126. [CrossRef]

32. Domínguez, S.; García, O.; Ezquer, M.; Rodríguez, M.J.; Lagunas, A.R.; Pérez-Conde, J.; Bravo, J. Optimization of 1D photonic crystals to minimize the reflectance of silicon solar cells. Photonics Nanostructures Fundam. Appl. 2012, 10, 46-53. [CrossRef]

33. Bermel, P.; Luo, C.; Zeng, L.; Kimerling, L.C.; Joannopoulos, J.D. Improving thin-film crystalline silicon solar cell efficiencies with photonic crystals. Opt. Express 2007, 15, 16986-17000. [CrossRef]

34. Zhang, S.; Zhao, H.; Li, X.; Li, Y.; Jin, Y.; Liu, X.; Shi, G.; Wong, P.K. A hierarchical SiPN/CN/MoSx photocathode with low internal resistance and strong light-absorption for solar hydrogen production. Appl. Catal. B Environ. 2021, 300, 120758. [CrossRef]

35. Jin, X.; Zhu, Q.; Feng, L.; Li, X.; Zhu, H.; Miao, H.; Zeng, Z.; Wang, Y.; Li, Y.; Wang, L.; et al. Light-Trapping SERS Substrate with Regular Bioinspired Arrays for Detecting Trace Dyes. ACS Appl. Mater. Interfaces 2021, 13, 11535-11542. [CrossRef]

36. Li, X.; Li, Y.; Wang, H.; Miao, H.; Zhu, H.; Liu, X.; Lin, H.; Shi, G. Fabrication of a Three-Dimensional Bionic Si/TiO2/MoS2 Photoelectrode for Efficient Solar Water Splitting. ACS Appl. Energy Mater. 2021, 4, 730-736. [CrossRef]

37. Zhou, S.; Wang, S.; Zhou, S.; Xu, H.; Zhao, J.; Wang, J.; Li, Y. An electrochromic supercapacitor based on an MOF derived hierarchical-porous $\mathrm{NiO}$ film. Nanoscale 2020, 12, 8934-8941. [CrossRef] [PubMed]

38. Xu, H.; Liu, L.; Teng, F.; Lu, N. Emission Enhancement of Fluorescent Molecules by Antireflective Arrays. Research 2019, $2019,1-8$. [CrossRef]

39. Xu, H.; Lu, N.; Qi, D.; Hao, J.; Gao, L.; Zhang, B.; Chi, L. Biomimetic Antireflective Si Nanopillar Arrays. Small 2008, 4, $1972-1975$. [CrossRef] [PubMed]

40. Sai, H.; Fujii, H.; Arafune, K.; Ohshita, Y.; Yamaguchi, M.; Kanamori, Y.; Yugami, H. Antireflective subwavelength structures on crystalline Si fabricated using directly formed anodic porous alumina masks. Appl. Phys. Lett. 2006, 88, 201116. [CrossRef]

41. Sun, C.H.; Min, W.L.; Linn, N.C.; Jiang, P.; Jiang, B. Templated fabrication of large area subwavelength antireflection gratings on silicon. Appl. Phys. Lett. 2007, 91, 231105. [CrossRef]

42. Sun, C.H.; Gonzalez, A.; Linn, N.C.; Jiang, P.; Jiang, B. Broadband moth-eye antireflection coatings on silicon. Appl. Phys. Lett. 2008, 92, 061112. [CrossRef]

43. Chang, Y.-J.; Chen, Y.-T. Broadband omnidirectional antireflection coatings for metal-backed solar cells optimized using simulated annealing algorithm incorporated with solar spectrum. Opt. Express 2011, 19, A875-A887. [CrossRef]

44. Mackay, T.G.; Lakhtakia, A. The Transfer-Matrix Method in Electromagnetics and Optics. Morgan Claypool 2020, 1, 1-26. [CrossRef]

45. Chern, G.W.; Wang, L.A. Transfer-matrix method based on perturbation expansion for periodic and quasi-periodic binary long-period gratings. J. Opt. Soc. Am. A 1999, 16, 2675-2689. [CrossRef]

46. Archambeault, B.; Ramahi, O.M.; Brench, C. The Finite-Difference Time-Domain Method. In EMI/EMC Computational Modeling Handbook; Springer: Boston, MA, USA, 1998.

47. Sheng, X.-Q.; Song, W. Finite-Difference Time-Domain Method. In Essentials of Computational Electromagnetics; IEEE: Piscataway, NJ, USA, 2012; pp. 207-241.

48. Yeng, Y.X.; Chou, J.B.; Rinnerbauer, V.; Shen, Y.; Kim, S.G.; Joannopoulos, J.D.; Soljacic, M.; Celanovi, I. Global optimization of omnidirectional wavelength selective emitters/absorbers based on dielectric-filled anti-reflection coated two-dimensional metallic photonic crystals. Opt. Express 2014, 22, 21711-21718. [CrossRef] [PubMed]

49. Mutitu, J.G.; Shi, S.; Chen, C.; Creazzo, T.; Barnett, A.; Honsberg, C.; Prather, W. Thin film silicon solar cell design based on photonic crystal and diffractive grating structures. Opt. Soc. Am. 2008, 16, 15238-15248.

50. Deinega, A.; John, S. Effective optical response of silicon to sunlight in the finite-difference time-domain method. Opt. Lett. 2011, 37, 112-114. [CrossRef] [PubMed]

51. Rajib, M.R.H.; Rana, S.M.; Hasan, M.R.; Amin, R.; Iqbal, M.S.; Anik, M.R.K.; Mia, M.N.H.; Hoq, M.; Hasan, M. Simulation of Mono Layer Solar Cell Using COMSOL and Fabrication in Particle Controlled BAEC Clean Room. Int. J. Eng. Res. Technol. (IJERT) 1973, 3, 295-300.

52. Banerjee, A. Enhanced Temperature Sensing by Using One-Dimensional Ternary Photonic Band Gap Structures. Prog. Electromagn. Res. Lett. 2009, 11, 129-137. [CrossRef]

53. Hoffmann, A.; Paetzold, U.W.; Zhang1, C.; Merdzhanova, T.; Lambertz, A.; Ulbrich, C.; Bittkau, K.; Rau, U. Advancing tandem solar cells by spectrally selective multilayer intermediate reflectors. Opt. Express 2014, 22, A1270-A1277. [CrossRef]

54. Philip, H.R. Optical properties of silicon nitride. J. Electrochim. Soc. 1973, 120, 295-300. [CrossRef] 
55. Podlucký, L.; Vincze, A.; Kováčová, S.; Chlpík, J.; Kováč, J.; Uherek, F. Optimization of Fabrication Process for SiON/SiOx Films Applicable as Optical Waveguides. Coatings 2021, 11, 574.010D. [CrossRef]

56. Tu, Y.-C.; Wang, S.-J.; Wu, C.-H.; Chang, K.-M.; Lin, T.-H.; Hung, C.-H.; Wu, J.-S. Improving Crystalline Silicon Solar Cell Efficiency Using Graded-Refractive-Index SiON/ZnO Nanostructures. Int. J. Photoenergy 2015, 2015, 1-6. [CrossRef]

57. Defranoux, C.; Piel, J.; Stehle, J. Deep ultra-violet measurements of SiON antireflective Coatings by spectroscopic ellipsometry. Thin Solid Films 1998, 313-314, 742-744. [CrossRef]

58. Park, S.; Park, H.; Kim, D.; Nam, J.; Yang, J.; Lee, D.; Min, B.K.; Kim, K.N.; Park, S.J.; Kim, S.; et al. Continuously deposited anti-reflection double layer of silicon nitride and silicon oxynitride for selective emitter solar cells by PECVD. Curr. Appl. Phys. 2017, 17, 517-521. [CrossRef]

59. Wörhoff, K.; Driessen, A.; Lambeck, P.; Hilderink, L.; Linders, P.; Popma, T. Plasma enhanced chemical vapor deposition silicon oxynitride optimized for application in integrated optics. Sensors Actuators A Phys. 1999, 74, 9-12. [CrossRef]

60. Huang, C.S.; Huang, C.; Chen, C.T.; Lin, S.C.; Kuo, L. SiON AR layer application for silicon solar cells. In Proceedings of the Conference Record of the Twenty-Ninth IEEE Photovoltaic Specialists Conference, New Orleans, LA, USA, $19-24$ May 2002.

61. Sun, X.; Chen, X.; Zhang, Z.; Sun, Z. Plasmon based antireflection coatings containing nanostructured Ag and silica medium. Appl. Surf. Sci. 2012, 258, 3785-3788. [CrossRef]

62. Nguyen, H.T.T.; Balaji, N.; Park, C.; Triet, N.M.; Le, A.H.T.; Lee, S.; Jeon, M.; Oh, D.; Dao, V.A.; Yi, J. Al2O3/SiON stack layers for effective surface passivation and anti-reflection of high efficiency n-type c-Si solar cells. Semicond. Sci. Technol. 2017, $32,025005$. [CrossRef]

63. Domínguez, S.; Cornago, I.; García, O.; Ezquer, M.; Rodríguez, M.J.; Lagunas, A.R.; Pérez-Conde, J.; Bravo, J. Design, optimization and fabrication of 2D photonic crystals for solar cells. Photonics Nanostructures Fundam. Appl. 2013, 11, 29-36. [CrossRef]

64. Aly, A.H.; Sayed, H.; Elsayed, H.A. Development of the Monolayer Silicon Solar Cell Based on Photonic Crystals. Silicon 2018, 11, 1377-1382. [CrossRef]

65. Elsayed, H.A.; Sayed, H.; Taha, T.; Alharbi, A.G.; Alenad, A.M.; Alshammari, B.A.; Ahmed, A.M.; Mehaney, A.; Aly, A.H. Simple and efficient design towards a significant improvement of the optical absorption of amorphous silicon solar cell. J. Quant. Spectrosc. Radiat. Transf. 2021, 275, 107890. [CrossRef]

66. Zhu, J.; Yu, Z.; Fan, S.; Cui, Y. Nanostructured photon management for high performance solar cells. Mater. Sci. Eng. R: Rep. 2010, 70, 330-340. [CrossRef]

67. Zaidi, S.H.; Gee, J.M.; Ruby, D.S. Diffraction grating structures in solar cells. In Proceedings of the Photovoltaic Specialists Conference, Anchorage, AK, USA, 15-22 September 2000; pp. 395-398. 